\title{
Total Polyphenol and Antioxidant Activity of Red Amaranth (Amaranthus tricolor L.) as Affected by Different Sunlight Level
}

\author{
Laila Khandaker, Md. B. Ali and Shinya Oba* \\ United Graduate School of Agriculture, Gifu University, Yanagido, Gifu 501-1193, Japan
}

\begin{abstract}
The total polyphenol content and antioxidant activity were compared in the leaves of seven red amaranth (Amaranthus tricolor $L_{\text {.) }}$ cultivars. The effect of the sunlight level on the accumulation of total polyphenol content and antioxidant activity was also investigated by growing plants under full sunlight and shaded conditions. The total phenolic content and antioxidant activity differed among the cultivars studied, and leaves from the cultivar 'Rocto Joba' and 'Rocto Lal' had the highest phenolics and antioxidant activity, respectively. These values were lowest in the leaves of the cultivar 'Red Queen'. Comparatively, red-fleshed cultivars had more total polyphenols and antioxidant activity than red green-fleshed cultivars. Total polyphenol and antioxidant activity were greater in leaves from plants grown under full sunlight without shading. The positive correlation between antioxidant activity and total polyphenols $\left(\mathrm{R}^{2}=\mathbf{0 . 8 2 4}\right)$ suggests that phenolic compounds are the major antioxidant components in red amaranth. The results indicate that red amaranth containing high phenolics may provide a source of dietary antioxidants. The combination of cultivar variation and responsiveness to specific growing conditions can create opportunities for the production and processing of vegetable red amaranth with improved antioxidant properties.
\end{abstract}

Key Words: antioxidant activity, polyphenol, red amaranth, sunlight level.

\section{Introduction}

Amaranths are probably the most important leafy vegetables of the lowland tropics of Africa and Asia, but are scarcely known in South America (Palada and Crossman, 1999). The flavor of raw and cooked vegetable amaranth was reported as equal to or better than that of spinach or other similar green vegetables (Abbott and Campbell, 1982). Among many species of vegetable amaranth, the main type, Amaranthus tricolor L., seems to have originated in South or Southeast Asia (Grubben and van Sloten, 1981) and then spread through the tropics and the temperate zone (Martin and Telek, 1979). Regardless of species, the choice of variety/ cultivar is influenced by individual preference for leaf color and taste. A.tricolor has various leaf colors such as white (light green), dark green, red, purple and variegated (Palada and Chang, 2003). The two main types grown as vegetables are loosely termed green amaranth and red amaranth.

Red amaranth is a wonderful vegetable with reddishveined dark green leaves or fully red to purple leaves,

Received; August 22, 2007. Accepted; March 6, 2008.

* Corresponding author (E-mail: soba@gifu-u.ac.jp). suitable for growing in warm weather, in which young leaves and stems can be harvested periodically. Red amaranth is also especially nutritious, rich in easily digestible minerals i.e., iron and calcium, as well as protein, vitamin $\mathrm{C}$, and beta-carotene (Islam et al., 2003a). The vitamins and minerals present in plants as natural or synthetic antioxidants have been linked to removing harmful molecules called free radicals in the body to help fight against infection and other conditions, including cancer, coronary artery disease, muscular degeneration, and serious eye diseases (Dasgupta and De, 2007). Besides antioxidant vitamins and minerals, fruits and vegetables contain flavonoids and related phenolics. Phenolics or polyphenols, as a class of nutrients, include bioflavonoids, organic acids and phenolic acids. The role of polyphenols in preventing many chronic diseases, including cancer, cardiovascular diseases, and diabetes, has been well documented (Scalbert et al., 2005). Initial findings confirmed that Amaranthus leaves are important sources of antioxidants (Sokkanha and Tiratanakul, 2006), but it is important to identify the major antioxidants and the antioxidant activity, specifically for red amaranth.

Red amaranth cultivars of different flesh color may differ in their phenolic content and antioxidant 
properties. In addition, cultivars with the same flesh color may differ in total phenolic content and antioxidant activity. Environmental factors, such as temperature and light levels play an important role in plant's anti-oxidant metabolism (Foyer et al., 1994; Smirnoff, 1995). Studies on other crops have reported that the antioxidant capacity and phenolic content of spinach and sweet potato leaf were greatly affected by artificial shading and light intensity (Howard et al., 2002; Islam et al., 2003b); therefore, it is hypothesized that changes in the sunlight level received by the plants may also affect the polyphenols and antioxidant components of shade-grown red amaranth. Several studies have reported correlations among the antioxidant activities and phytochemical concentrations of various food commodities (Awika et al., 2003); however, this type of information is not available for red amaranth. Information on the total phenolics and antioxidant activity of red amaranth would also be helpful for increasing the awareness of consumers regarding the level of beneficial phytochemicals present in this nutritious vegetable. In addition, investigation of the effect of the sunlight level on phenolic content and antioxidants in red amaranth may identify new cultivation methods to enhance its nutritional value. The objectives of this study were (1) to compare red amaranth cultivars for their total polyphenol content and antioxidant activity, and (2) to identify the level of sunlight as suitable growing conditions to achieve the desired antioxidant properties in red amaranth.

\section{Materials and Methods}

\section{Plant materials and culture method}

Seven red amaranth cultivars (Table 1) collected from Bangladesh were grown in the field to compare their total polyphenol and antioxidant activity. On May 30 2006 , seeds were sown directly in a field plot $(1 \mathrm{~m}(\times)$ $1 \mathrm{~m}$ ) in rows, which were arranged in a randomized complete block design with three replications. The field plot was irrigated in split application as necessary and fertilized with mixed fertilizer (10:10:10 NPK), $50 \mathrm{~g}$ as basal dose and $50 \mathrm{~g} 10$ days after sowing the seeds in each plot. Nine randomly selected plants were collected with roots at the edible stage 28 days after sowing (DAS) to measure horticultural growth parameters, such as plant height, and whole plant fresh and dry weight.

\section{Shading for different light levels/intensity}

A red amaranth cultivar, 'Altopati', was sown in rows in the field on 30 May 2006. After germination, plants were covered with synthetic shade net. Different sunlight levels were achieved under 1, 2, and 3 layers of white and black neutral-density synthetic shade net. The height of the shading material was kept at least $1 \mathrm{~m}$ above the top of plants. The $100 \%$ sunlight (no shading) treatment was adjacent to the shading experiment. All treatments for sunlight level (shading and no shading) were arranged in a randomized complete block design with three replications. Light intensity was measured with a Quantum sensor light meter with a Separate Sensor (QMSS) from germination to harvesting. Each reading was expressed as $\mu \mathrm{mol} \mathrm{m} \mathrm{m}^{-2} \mathrm{~S}^{-1}$ and converted into percentage of ambient light intensity. Temperature was recorded during the grown period under different growing conditions.

\section{Leaf color analysis}

The color parameters $\mathrm{L}^{*}, \mathrm{a}^{*}$, and $\mathrm{b}^{*}$ values of leaves from each cultivar were measured by a colorimeter (CSSharpener, Toppan, Japan). $L^{*}$ measures the sample's lightness; $\mathrm{a}^{*}$ measures redness $\left(\mathrm{a}^{*}=\mathrm{red}\right)$ and $\mathrm{b}^{*}$ is related to yellowness $\left(\mathrm{b}^{*}=\right.$ yellow). The color index $(\mathrm{CI})$ was calculated using the equation $\mathrm{CI}=1000(\times) \mathrm{a}^{*} / \mathrm{L}(\times) \mathrm{b}^{*}$ (Mazzuz, 1996) to evaluate the relation between leaf color, polyphenols, and antioxidants. The visual appearance (Table 1 and Fig. 1) of included cultivars was classified as red-fleshed $(R)$ and red green-fleshed (RG).

\section{Extraction of samples for chemical analysis}

Leaves were harvested at the edible stage, 28 DAS and dried overnight in an oven for chemical analysis. One gram of dried leaf of each cultivar was ground and dissolved in $40 \mathrm{~mL}$ of $90 \%$ methanol. The tightly capped bottle was placed in a water bath (Thomastant T-N22S, Thomas Kagaku Co. Ltd., Japan) with shaking at $80^{\circ} \mathrm{C}$ temperature. After $1 \mathrm{~h}$, the extract was cooled and filtered for further analytical assays total polyphenol and antioxidant activity.

\section{Determination of total polyphenols}

Total phenolic content in red amaranth was determined with Folin-Ciocalteu reagent according to the method of Slinkard and Singleton (1977) using gallic acid as a standard phenolic compound. Briefly, $50 \mu \mathrm{L}$ of leaf extract solution was placed in a test tube, then $1 \mathrm{ml}$ of Folin-Ciocalteu reagent (previously diluted by distilled water; Reagent: Water $=1: 4$ ) was added and the content was mixed thoroughly. After $3 \mathrm{~min}, 1 \mathrm{~mL}$ of $\mathrm{Na}_{2} \mathrm{CO}_{3}$ $(10 \%)$ was added, the mixture was allowed to stand for $1 \mathrm{~h}$ in the dark. Absorbance was measured at $760 \mathrm{~nm}$ using a (U-1800, HITACHI, Tokyo, Japan) spectrophotometer. The concentration of total phenolic compounds in leaf extracts was determined as micrograms of gallic acid equivalent using an equation obtained from a standard gallic acid graph. Results are expressed as mg/ $100 \mathrm{~g}$ gallic acid equivalent (GAE) of dry mass.

\section{Anti-oxidant activity assay}

Antioxidant activity was measured by the diphenylpicrylhydrazyl (DPPH) radical degradation method (Burits and Bucar, 2000). Briefly, $10 \mu \mathrm{L}$ of leaf extract solution (three replicates) was introduced into test tubes, and $4 \mathrm{~mL}$ distilled water and $1 \mathrm{~mL}$ of $250 \mu \mathrm{M} \mathrm{DPPH}$ solution was added. The tubes were mixed and allowed 
to stand for $30 \mathrm{~min}$ in the dark. Absorbance was read against a blank at $517 \mathrm{~nm}$ using a (U-1800, HITACHI) spectrophotometer. Antioxidant activity was calculated as the percent of inhibition relative to the control using the following equation: Antioxidant activity $(\%)=\left(\mathrm{A}_{\text {blank }}\right.$ $-\mathrm{A}_{\text {sample }}\left(\mathrm{A}_{\text {blank }}\right) \times 100$, where $A_{\text {blank }}$ is the absorbance of the control reaction (control consisted of $10 \mu \mathrm{L}$, methanol instead of sample extract), and $A_{\text {sample }}$ is the absorbance of the test compound.

\section{Statistical Analysis}

A complete randomized design with three replications was used. Data were analyzed using Tukey's multiple comparison test $(P<0.05)$ via ANOVA (Nagata and Yoshida, 1997). The PC software 'Excel Statistics' (Version 5.0, Esumi Co. Ltd., Japan) was used for the calculations.

\section{Results and Discussion}

\section{Total polyphenol and antioxidant activity in seven} cultivars

The total polyphenol and antioxidant activities of the seven red amaranth cultivar used in this study are presented in Table 1. The total phenolic content was highest, $2.29 \mathrm{mg} / 100 \mathrm{~g}$ GAE, for 'Rocto Joba' (redfleshed) and lowest, $1.73 \mathrm{mg} / 100 \mathrm{~g} \mathrm{GAE}$, for 'Red Queen' (red green-fleshed). The red-fleshed cultivars 'Rocto Joba', 'Altopati', 'BARI-1', and 'Rocto Lal' had higher levels of total polyphenol followed by the red green-fleshed cultivars 'Rampali', 'Baromashi', and 'Red Queen', respectively. The antioxidant activity of red amaranth varied in a wide range, red-fleshed cultivar 'Rocto Lal' had the highest (12.78\%), and red greenfleshed cultivar 'Red Queen' had the lowest (8.52\%) levels. Antioxidant activity fell in the order: 'Rocto Lal' $>$ 'Rocto Joba' > 'BARI-1' > 'Altopati' > 'Rampali' > 'Baromashi' > 'Red Queen'. In comparisons of plant height, fresh and dry weight, red-fleshed cultivars 'Rocto Joba', 'Altopati', 'Rocto Lal' and 'BARI-1' had superior yield performance than the red green-flesh cultivars (Table 1). Highest fresh and dry weights were obtained from the cultivar 'Rocto Joba' followed by 'BARI-1' and 'Altopati', whereas the lowest producer was 'Baromashi'. The results of color analysis indicated that the color index varied among the cultivars. The $\mathrm{L}^{*}, \mathrm{a}^{*}$, and $b^{*}$ values (data not shown) for samples varied among varieties and 'Rocto Joba', 'BARI-1', and 'Altopati' had a superior color index to the other cultivars (Table 1).

The results indicated that red-fleshed cultivars with a better color index tended to be associated with high total polyphenol and antioxidant activity. Aside from red amaranth, other food commodities, such as sweet potatoes and sorghum, show a similar relationship between color intensity and antioxidant activity. Brown and black sorghum had the highest levels of freely extractable polyphenols (Awika et al., 2003). Similar results have been documented for colored fruit and vegetables such as black carrots, beetroot, red oak and black bayberry cultivars which had much higher antioxidant activity and polyphenols than less colored ones (Bao et al., 2005; Nicolle et al., 2004; Wang et al., 1997). In general, there was a trend towards increased antioxidant activity with increased total phenolic content. The variation of antioxidant activity among cultivars was much wider than that of total polyphenol content. Although vegetables contain antioxidants such as proteins, ascorbate, and carotenoids, they did not contribute significantly to antioxidant activity in their

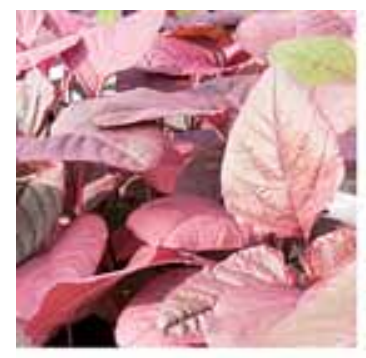

1

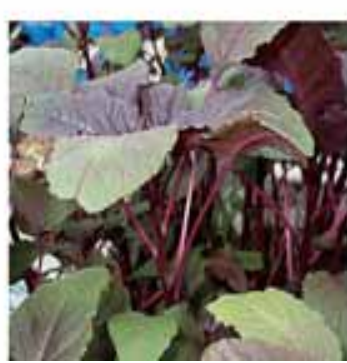

5

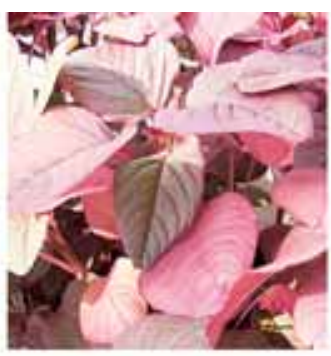

2

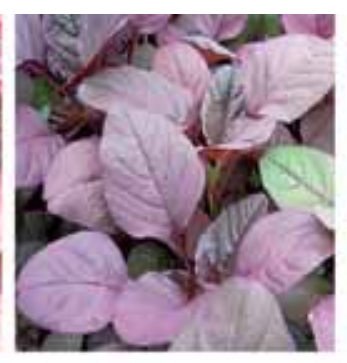

3

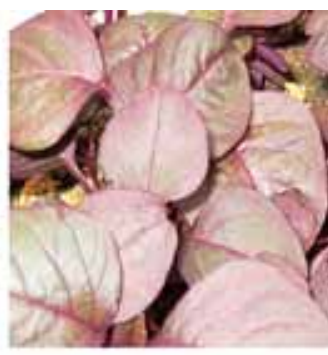

4

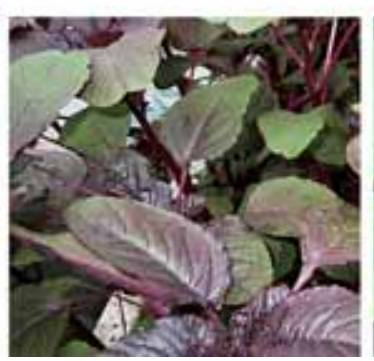

6

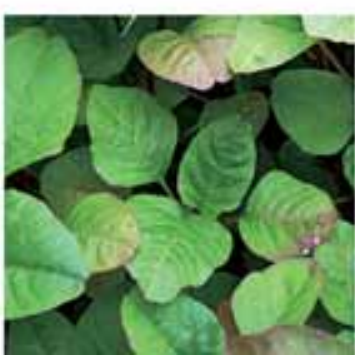

7

Fig. 1. Leaf color of seven red amaranth cultivars, left to right, 1) 'Rocto Joba', 2) 'Altopati', 3) 'BARI-1', 4) 'Rocto Lal', 5) 'Rampali', 6) 'Baromashi', and 7) 'Red Queen'. 
Table 1. Plant height, fresh weight, dry weight, total polyphenol content, antioxidant activity, and leaf color index of seven red amaranth cultivars.

\begin{tabular}{|c|c|c|c|c|c|c|c|c|}
\hline Cultivar name & Cultivar type & $\begin{array}{l}\text { Plant height } \\
(\mathrm{cm})\end{array}$ & $\begin{array}{l}\text { Fresh weight/ } \\
\text { plant }(\mathrm{g})\end{array}$ & $\begin{array}{l}\text { Dry weight/ } \\
\text { plant }(\mathrm{g})\end{array}$ & $\begin{array}{c}\text { Total } \\
\text { polyphenol } \\
\text { (mg/100 g } \\
\text { GAE) }\end{array}$ & $\begin{array}{l}\text { Antioxidant } \\
\text { activity (\%) }\end{array}$ & $\begin{array}{l}\text { Leaf color index } \\
\text { (CI) }\end{array}$ & $\begin{array}{c}\text { Leaf color } \\
\text { type }\end{array}$ \\
\hline BARI-1 & Improved & $28.68 \mathrm{abc}$ & $44.10 \mathrm{f}$ & $5.10 \mathrm{~b}$ & $2.27 \mathrm{c}$ & $12.41 \mathrm{ab}$ & $104.98 \mathrm{f}$ & $\mathrm{R}$ \\
\hline Rocto Joba & Local & $31.60 \mathrm{c}$ & $49.04 \mathrm{~g}$ & $6.56 \mathrm{~d}$ & $2.29 \mathrm{c}$ & $12.59 \mathrm{~b}$ & $105.71 \mathrm{f}$ & $\mathrm{R}$ \\
\hline Rocto Lal & Local & $30.80 \mathrm{c}$ & $38.58 \mathrm{~d}$ & $5.14 b c$ & $2.05 b$ & $12.78 \mathrm{~b}$ & $90.68 \mathrm{~d}$ & $\mathrm{R}$ \\
\hline Red Queen & Local & $26.24 \mathrm{abc}$ & $30.24 b$ & $5.11 \mathrm{~b}$ & $1.73 \mathrm{a}$ & $8.52 \mathrm{a}$ & $38.56 \mathrm{a}$ & RG \\
\hline Rampali & Local & $21.26 \mathrm{ab}$ & $34.25 \mathrm{c}$ & $5.23 \mathrm{c}$ & $1.83 \mathrm{a}$ & $10.18 \mathrm{ab}$ & $86.49 \mathrm{c}$ & $\mathrm{RG}$ \\
\hline Baromashi & Local & $20.08 \mathrm{a}$ & $23.50 \mathrm{a}$ & $3.69 \mathrm{a}$ & $1.74 \mathrm{a}$ & $8.92 \mathrm{ab}$ & $63.87 \mathrm{~b}$ & RG \\
\hline Altopati & Improved & $28.84 \mathrm{bc}$ & $41.92 \mathrm{e}$ & $6.47 \mathrm{~d}$ & $2.28 \mathrm{c}$ & $11.30 \mathrm{ab}$ & $100.41 \mathrm{e}$ & $\mathrm{R}$ \\
\hline
\end{tabular}

Means having the same letter within the column did not differ significantly according to Tukey's multiple comparison test $(P<0.05)$ via ANOVA. Leaf color type: R—red-fleshed; RG—red green-fleshed.

model (Tsushida et al., 1994). An increased number of hydroxyl groups or amino groups in the phytochemical's molecular structure led to higher antioxidant activity (Cai et al., 2003). As A.tricolor L. is characterized by a higher level of red-violet pigment betacyanin (Iwamoto et al., 2001), we similarly found at red-fleshed cultivars ('Rocto Joba', 'BARI-1', 'Altopati', etc.) contain a higher level of colorant pigment betacyanin compared to red-greenish leaf cultivars (unpublished data). Hence we speculated that hydroxyl and amino groups of red amaranth phenolics and betacyanin enhance antioxidant activity. It was previously reported that the antioxidant activity of green amaranth is higher than sweet and sacred basil (Sokkanha and Tiratanakul, 2006). In 2002, Sato also reported that total polyphenol and antioxidant activity in amaranths (Amaranthus spp.) were higher than or similar to malaber spinach, basil and sweet potato vine. Although some fruits and vegetables have an astringent taste attributed to phenolic compounds or tannins, vegetable amaranth has an acceptable taste as it is consumed as a popular and tasty vegetable in many parts of the world (Sealy et al., 1990); therefore, red amaranth would be a healthy food choice for consumers, as well as a potential source of natural antioxidants, namely polyphenols.

A significant $(P<0.05)$ linear correlation $\left(\mathrm{R}^{2}=0.824\right)$ was found between total polyphenol and antioxidant activity (Fig. 2), indicating that phenolics were the major contributor to antioxidant activity of red amaranth. This was very similar to many other plant species, such as fruits, vegetables, and medicinal plants (Cai et al., 2004; Soong and Barlow, 2004; Wong et al., 2006). Phenolics enhance antioxidant activity due to their redox properties, which allow them to act as reducing agents, hydrogen donors and singlet oxygen quenchers (RiceEvans et al., 1996). A highly significant correlation $\left(\mathrm{R}^{2}\right.$ $=0.9361, P<0.05$ ) between antioxidant activity and total phenolic content was also reported for red cabbage (Karadeniz et al., 2005). Thus, the antioxidant activity of red amaranth is due primarily to its phenolic content, which can be used as an indicator for assessing the antioxidant activity of red amaranth.

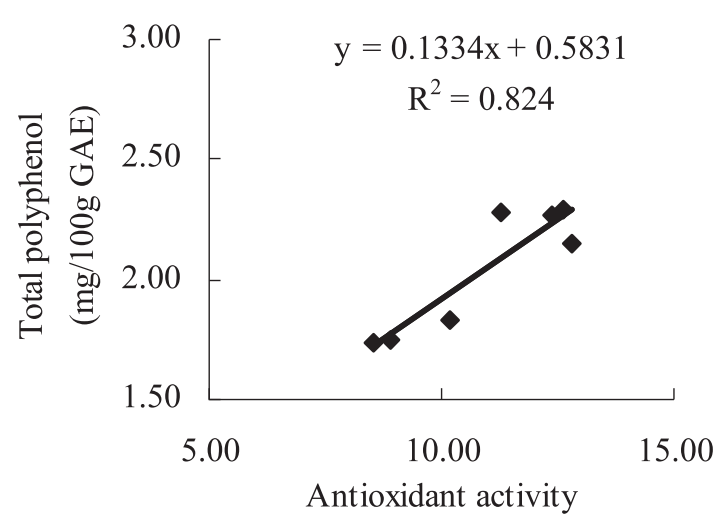

(\%)

Fig. 2. Correlation of antioxidant activity and total polyphenol content in leaves of seven red amaranth cultivars.

\section{Effect of sunlight level on total polyphenol and} antioxidant activity accumulation

The use of shade netting may induces changes in the microclimate other than light quantity alone. In this study, white and black shade net was used in single, double and triple layers; thus, plants under shade absorb different wavelengths and light quantity that consequently affect light quality. The mean temperature was $29 \pm 2^{\circ} \mathrm{C}$ during the growing period, and differences were found among the shading types, ranging from $24^{\circ} \mathrm{C}$ (shaded by triple layer black net) to $28^{\circ} \mathrm{C}$ (shaded by single layer white net). Under single, double and triple white shade net, plants received $64 \%, 55 \%$, and $42 \%$ ambient sunlight compared to non-shaded plants, and using single, double and triple black synthetic net, ambient light was $50 \%, 31 \%$, and $17 \%$, respectively (Table 2). Shading affected the total polyphenol content and red amaranth grown in full sunlight $(100 \%)$ without shade had a significantly greater accumulation than the $17 \%$ (triple black net) to $64 \%$ (single white net) shading treatments (Table 2). Like polyphenol accumulation, antioxidant activity in leaves under full sunlight was significantly greater than in shading treatments.

Total polyphenols were significantly higher and antioxidant activity was more than six-fold higher in the 
Table 2. Total polyphenol and antioxidant activity in leaves of red amaranth cultivar, 'Altopati', at different sunlight levels.

\begin{tabular}{lcccc}
\hline \hline Growth condition & $\begin{array}{c}\text { Sunlight level/Intensity } \\
\left(\mu \mathrm{mol} \mathrm{m} \mathrm{m}^{-2} \mathrm{~S}^{-1}\right.\end{array}$ & $\begin{array}{c}\text { Ambient light } \\
(\%)\end{array}$ & $\begin{array}{c}\text { Total polyphenol } \\
(\mathrm{mg} / 100 \mathrm{~g} \mathrm{GAE})\end{array}$ & $\begin{array}{c}\text { Antioxidant activity } \\
(\%)\end{array}$ \\
\hline Open & 1235 & 100 & $2.54 \mathrm{~d}$ & $11.74 \mathrm{e}$ \\
Single white net & 789 & 64 & $2.21 \mathrm{c}$ & $9.81 \mathrm{~d}$ \\
Double white net & 678 & 55 & $2.18 \mathrm{c}$ & $8.22 \mathrm{~cd}$ \\
Triple white net & 518 & 42 & $2.05 \mathrm{abc}$ & $4.12 \mathrm{~b}$ \\
Single black net & 615 & 50 & $2.14 \mathrm{bc}$ & $7.57 \mathrm{c}$ \\
Double black net & 382 & 31 & $1.99 \mathrm{ab}$ & $3.67 \mathrm{~b}$ \\
Triple black net & 203 & 17 & $1.88 \mathrm{a}$ & $1.72 \mathrm{a}$ \\
\hline
\end{tabular}

Means having same letter within the column did not differ significantly according to Tukey's multiple comparison test $(\mathrm{P}<0.05)$ via ANOVA.

(a)

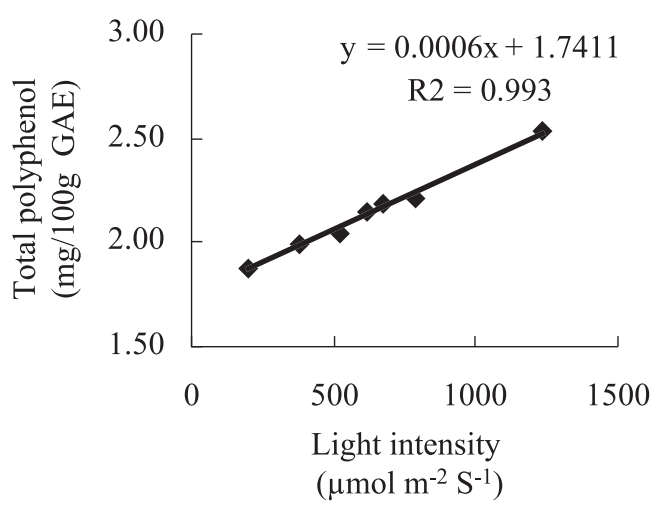

(b)

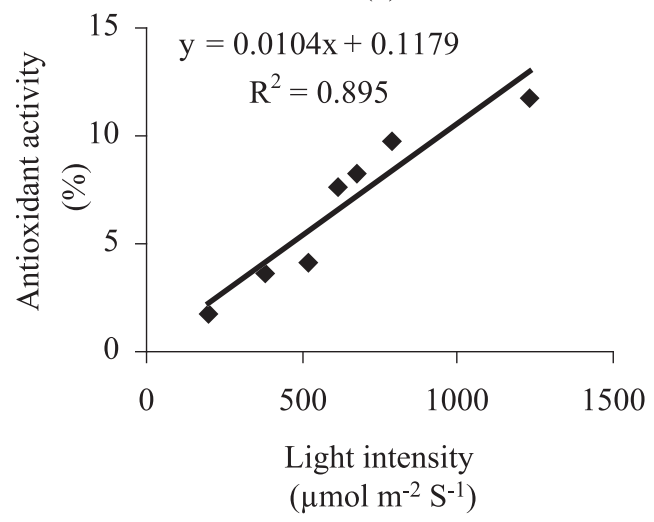

Fig. 3. Relationship between: (a) sunlight levels and total polyphenol, and (b) sunlight levels and antioxidant activity of red amaranth cultivar, 'Altopati'.

leaves of plants grown in full sunlight (light intensity$1235 \mu \mathrm{mol} \mathrm{m} \mathrm{m}^{-2} \mathrm{~S}^{-1}$ ) than triple black net-shaded leaves $\left(203 \mu \mathrm{mol} \mathrm{m}^{-2} \mathrm{~S}^{-1}\right)$. Reena and Kalidas (2005) also found that total phenolic content and antioxidant activity in light-germinated corn were almost three-fold higher than in dark-germinated corn. The results of this study suggested that plants grown under average temperature, $29 \pm 2{ }^{\circ} \mathrm{C}$ and without shading, accumulate a higher concentration of polyphenols and antioxidants than plants grown under comparatively lower temperature and shaded conditions. The decreased production of total polyphenols in leaves grown under shade is probably due to reduced stimulation of phenolic production by light (Islam et al., 2003b). Logan et al. (1998) observed that full sunlight-grown plants (Cucurbita pepo L. and Vinca major L) had considerably higher activities of leaf antioxidant enzymes and superoxide dismutase, than of deep-shaded plants. We suppose that the greater activities of antioxidative enzymes, availability of carbohydrate, and more photosynthetic efficiency of red amaranth plants grown in full sunlight enhanced the total polyphenol contents and antioxidant activities more than in the shaded plants. Total polyphenol content and antioxidant activity increased proportionally to the light intensity (Fig. 3a, b). The $\mathrm{R}^{2}$ value indicated that the sunlight level or light intensity has a strong role in the accumulation of phenolics and antioxidants in red amaranth. We also found positive and significant correlations $\left(\mathrm{R}^{2}=0.8806, P<0.05\right)$ between the total polyphenols and antioxidant activity from shade treatments. Different light levels also affected the plant height, number of leaves, leaf size, and fresh and dry yield (Table 3 ). The plant height under $100 \%$ sunlight $(27.08 \mathrm{~cm})$ was $37.3 \%$ higher than that of plants under triple black net (17\%), and plant biomass under $100 \%$ sunlight (4.94 g/plant) was $94.3 \%$ heavier than that under triple black net; therefore, it can be noted that different light intensity had a significant effect on the accumulation of total polyphenols and antioxidants as well as on yield in red amaranth.

Collectively, our data emphasize that 'shade treatment differences' for antioxidant activity were greater than 'cultivar differences' (Tables 1 and 2) and, in this case, polyphenol variation was more or less similar. The variation of antioxidant activity among cultivars was 1.5 -fold, whereas 6.8 -fold variations were observed in shading treatments. Compared with polyphenols, the levels of antioxidant activity by other phytochemicals of red amaranth appear to be more sensitive to growing conditions. It was reported that plant antioxidants vary 
Table 3. Effect of shading net on the morphological characteristics of red amaranth cultivar, 'Altopati'.

\begin{tabular}{lcccccc}
\hline \hline & \multicolumn{5}{c}{ Growth parameter } \\
\cline { 2 - 7 } Growth condition/ambient light & $\begin{array}{c}\text { Plant height } \\
(\mathrm{cm})\end{array}$ & $\begin{array}{c}\text { Stem length } \\
(\mathrm{cm})\end{array}$ & $\begin{array}{c}\text { Leaf length } \\
(\mathrm{cm})\end{array}$ & $\begin{array}{c}\text { Leaf width } \\
(\mathrm{cm})\end{array}$ & $\begin{array}{c}\text { Fresh weight/Plant } \\
(\mathrm{g})\end{array}$ & $\begin{array}{c}\text { Dry weight/Plant } \\
(\mathrm{g})\end{array}$ \\
\hline Open $(100 \%)$ & $27.08 \mathrm{f}$ & $15.86 \mathrm{e}$ & $7.10 \mathrm{c}$ & $5.33 \mathrm{c}$ & $30.37 \mathrm{~d}$ & $4.94 \mathrm{f}$ \\
Single white net $(64 \%)$ & $25.11 \mathrm{e}$ & $15.09 \mathrm{de}$ & $7.08 \mathrm{c}$ & $5.18 \mathrm{bc}$ & $27.36 \mathrm{~d}$ & $3.72 \mathrm{e}$ \\
Double white net $(55 \%)$ & $23.54 \mathrm{de}$ & $14.09 \mathrm{~cd}$ & $6.43 \mathrm{~b}$ & $4.98 \mathrm{bc}$ & $20.30 \mathrm{c}$ & $2.57 \mathrm{~d}$ \\
Triple white net $(42 \%)$ & $22.06 \mathrm{~cd}$ & 13.20 & $6.40 \mathrm{~b}$ & $4.86 \mathrm{~b}$ & $15.07 \mathrm{~b}$ & $1.16 \mathrm{c}$ \\
Single black net $(50 \%)$ & $21.49 \mathrm{c}$ & $13.09 \mathrm{cc}$ & $6.09 \mathrm{~b}$ & $4.80 \mathrm{~b}$ & $13.43 \mathrm{~b}$ & $1.08 \mathrm{c}$ \\
Double black net $(31 \%)$ & $19.09 \mathrm{~b}$ & $11.39 \mathrm{~b}$ & $5.18 \mathrm{a}$ & $3.49 \mathrm{a}$ & $7.94 \mathrm{a}$ & $0.56 \mathrm{~b}$ \\
Triple black net $(17 \%)$ & $17.00 \mathrm{a}$ & $9.96 \mathrm{a}$ & $5.16 \mathrm{a}$ & $3.30 \mathrm{a}$ & $5.58 \mathrm{a}$ & $0.28 \mathrm{a}$ \\
\hline
\end{tabular}

Means having the same letter within the column did not differ significantly according to Tukey's multiple comparison test $(P<0.05)$ via ANOVA.

due to air temperature, light intensity, harvesting season and genetic factors (Tamura, 2002). Hence, antioxidant activity varies in red amaranth due to influences of cultivar variations as well as temperature and sunlight level.

Thus, data from the current study support the conclusion that red-fleshed cultivars of red amaranth tended to be associated with high total polyphenol and antioxidant activity. The high amount of betacyanin in red amaranth, which gives its deep red hue, enhances antioxidant activity along with phenolic compounds. The significant relationship between total polyphenols and anti-oxidant activity indicated that total phenolic contents can be used as an indicator for assessing the antioxidant activities of the vegetable red amaranth. As a potential source of natural antioxidants red amaranth is a healthy food choice for consumers. The results also indicated that growing red amaranth in full sunlight enhances the accumulation of total polyphenols and antioxidants. The combination of cultivar variation and responsiveness to specific growing conditions can create opportunities for the production and processing of vegetable red amaranth with improved antioxidant properties.

\section{Literature Cited}

Abbott, J. A. and T. A. Campbell. 1982. Sensory evaluation of vegetable amaranth (Amaranthus spp.). HortScience 17: 409_ 410.

Awika, J. M., L. W. Rooney, X. Wu, R. L. Prior and L. CisnerosZevallos. 2003. Screening methods to measure antioxidant activity of sorghum (Sorghum bicolor) and sorghum products. J. Agric. Food Chem. 51: 6657-6662.

Bao, J., Y. Cai, M. Sun, G. Wang and H. Corke. 2005. Anthocyanins, flavonols, and free radical scavenging activity of Chinese bayberry (Myrica rubra) extracts and their color properties and stability. J. Agric. Food Chem. 53: 2327-2332.

Burits, M. and F. Bucar. 2000. Antioxidant activity of Nigella sativa essential oil. Phytotheraphy Res. 14: 323-328.

Cai, Y., Q. Luo, M. Sun and H. Corke. 2004. Antioxidant activity and phenolic compounds of 112 traditional Chinese medicinal plants associated with anticancer. Life Sci. 74: 2157-2184.

Cai, Y. Z., M. Sun and H. Corke. 2003. Antioxidant activity of betalains from plants of the Amaranthaceae. J. Agric. Food Chem. 51: 2288-2294.
Dasgupta, N. and B. De. 2007. Antioxidant activity of some leafy vegetables of India: A comparative study. Food Chem. 101: 471-474.

Foyer, C. H., M. Lelandais and K. J. Kunert. 1994. Photooxidative stress in plants. Physiol. Plant. 92: 696-717.

Grubben, G. J. H. and D. H. van Sloten. 1981. Genetic Resources of Amaranths. p. 57. Intl. Board for Plant Genetic Resources, Food and Agric. Org. Rome, Italy.

Howard, L. R., N. Pandjaitan, T. Morelock and M. I. Gil. 2002. Antioxidant capacity and phenolic content of spinach as affected by genetics and growing season. J. Agric. Food Chem. 50: 5891-5896.

Islam, Md. S., J. A. Khatoon, M. Alamgir and Md. A. Hossain. 2003a. Nutritional status of red amaranth as influenced by selected pesticides. Pakistan J. Biol. Sci. 6: 2044-2049.

Islam, M. S., M. Yoshimoto, K. Ishigure, S. Okuno and O. Yamakawa. 2003b. Effect of artificial shading and temperature on radical scavenging activity and polyphenolic composition in sweetpotato (Ipomoea batatas L.) leaves. J. Amer. Soc. Hort. Sci. 128: 182-187.

Iwamoto, K., H. Fukuda and M. Sugiyama. 2001. Elimination of POR expression correlates with red leaf formation in Amaranthus tricolor. Plant J. 27: 275-284.

Karadeniz, F., H. S. Burdurlu, N. Koca and Y. Soyer. 2005. Antioxidant activity of selected fruits and vegetables grown in Turkey. Turk. J. Agric. For. 29: 297-303.

Logan, B. A., B. Demmig-Adams, W. W. Adams and S. C. Grace. 1998. Antioxidants and xanthophyll cycle-dependent energy dissipation in Cucurbita pepo L. and Vinca major L. acclimated to four growth PPFDs in the field. J. Exp. Bot. 49: $1869-1879$.

Martin, F. W. and L. Telek. 1979. Vegetables for the hot humid tropics. Part 6: Amaranth and Celosia. U.S. Dept. of Agric.

Mazzuz, C. F. 1996. Calidad de frutos cítricos: manual para sugestion desde la recoleccion hasta la expedicion. Edicionas de Horticultura.

Nagata, Y. and M. Yoshida. 1997. Basis of statistical multiple comparison tests (In Japanese). Scientist Co., Tokyo.

Nicolle, C., A. Carnat, D. Fraisse, J. L. Lamaison, E. Rock, H. Michel, P. Amouroux and C. Remesy. 2004. Characterisation and variation of antioxidant micronutrients in lettuce (Lactuca sativa folium). J. Sc. Food Agric. 84: 2061-2069.

Palada, M. C. and L. C. Chang. 2003. Suggested cultural practices for vegetable amaranth. International Cooperators Guide, Asian Vegetable Research and Development Centre (AVRDC), Taiwan.

Palada, M. C. and S. M. A. Crossman. 1999. Evaluation of tropical leaf vegetables in the Virgin Islands. p. 388-393. In: J. Janick (ed.). Perspectives on new crops and new uses. ASHS Press, 
Alexandria. VA.

Rice-Evans, C. A., N. J. Miller and G. Pagana. 1996. Structureantioxidant activity relationships of flavonoids and phenolic acids. Free Radical Biol. Med. 20: 933-956.

Reena, R. and S. Kalidas. 2005. Developmental stimulation of total phenolics and related antioxidant activity in light- and dark-germinated corn by natural elicitors. Process Biochem. 40: 1721-1732.

Sato, T. 2002. Evaluation of antioxidant activity of indigenous vegetables from South and South East Asia. Annual report. Japan International Research Center for Agricultural Sciences (JIRCAS).

Scalbert, A., C. Manach, C. Morand, C. Remesy and L. Jimenez. 2005. Dietary polyphenols and the prevention of diseases. Crit. Rev. Food Sci. Nutr. 45: 287-306.

Sealy, R. L., E. L. McWilliams, J. Novak, F. Fong and C. M. Kenerley. 1990. Vegetable amaranths: Cultivar selection for summer production in the south. p. 396-398. In: J. Janick and J. E. Simon (eds.). Advances in new crops. Timber Press, Portland.

Slinkard, K. and V. L. Singleton. 1977. Total phenol analysis: automation and comparison with manual methods. Amer. J. Enol. Viticult. 28: 49-55.

Smirnoff, H. 1995. Antioxidant systems and plant response to the environment. p. 217-244. In: H. Smirnoff (ed.). Environment and plant meta bolism. BIOS Sci. Publi. Oxford.

Sokkanha, S. and V. Tiratanakul. 2006. Effect of plastic vinyl cover and shading on the antioxidants level of selected indigenous vegetables. 24 Regional training course in vegetable production, research and extension. Asian Vegetable Research and Development Centre (AVRDC).

Soong, Y. Y. and P. J. Barlow. 2004. Antioxidant activity and phenolic content of selected fruit seeds. Food Chem. 88: 411417.

Tamura, Y. 2002. Environmental changes and genetic variation of accumulation of bioactive compounds in plantain (Plantago lanceolata L.). Bull. Natl. Agric. Res. Cent. Tohoku Reg. 100: 75-92.

Tsushida, T., M. Suzuki and M. Kurogi. 1994. Evaluation of antioxidant activity of vegetable extracts and determination of some active compounds. J. Jap. Soc. Food Sci. Tech. 41: 611-618.

Wang, H., G. Cao and R. L. Prior. 1997. Oxygen radical absorbing capacity of anthocyanin. J. Agric. Food Chem. 45: 304-309.

Wong, C. C., H. B. Li, K. W. Cheng and F. Chen. 2006. A systematic survey of antioxidant activity of 30 Chinese medicinal plants using the ferric reducing antioxidant power assay. Food Chem. 97: 705-711. 